\title{
Factors affecting outcomes of EU-supported investments in innovation among SMEs in the Greater Poland (Wielkopolska) region, Poland
}

Pawel Mikołajczak ${ }^{\mathbf{1}}$ (Corresponding author)

Department of Money and Banking

Poznań University of Economics

Aleje Niepodległości 10, 61-875 Poznań

E-mail: pawel.mikolajczak@ue.poznan.pl

Tel: +48618543374

\section{Jacek Pawlak ${ }^{2}$}

Centre for Transport Studies \& Urban Systems Laboratory

Imperial College London

South Kensington Campus

London SW7 2AZ

United Kingdom

E-mail: jacek.pawlak@imperial.ac.uk

Tel: +44 (0) 2075942705

Word count: 8,961

\footnotetext{
${ }^{1}$ Dr Pawel Mikolajczak is an adjunct professor at the Department of Banking at Poznań University of Economics. His area of expertise is economics of Small and Medium Enterprises with a focus on innovation capabilities and funding. Recently, he has also been involved in research on economics of social enterprises and their development opportunities in Central Europe.

${ }^{2}$ Dr Jacek Pawlak is a Post-doctoral Research Associate at Imperial College London. His background is in Economics, Geography, and Transport with research interests in quantitative modelling of impacts of information and communication technologies, microeconomics, and travel behavior. Since April 2014, he has been part of Cisco Collaborative Research and Emerging Technologies innovation team (Cisco CREATE).
} 


\section{Structured Abstract:}

Purpose: The European Union offers support mechanisms to help small and medium sized enterprises (SMEs) to innovate and grow. Given the substantial contribution of SMEs to national economies, the present paper explores what factors tend to be associated with the success of EU-supported innovation by SMEs in Poland during its early post-accession period.

Design/methodology/approach: A conceptual model relating the type of innovation, investment purpose, funding type and financial readiness, location and collaboration possibilities, company size and sector of operation to changes in the capital base, employment, unit price and revenue is proposed. This model is operationalised and estimated as a structural equations model and estimated using a sample of 110 SMEs surveyed in 2008 in the Greater Poland (Wielkopolska) region in Poland.

Findings: Two approaches to the successful use of innovation support have been observed among the studied companies. The first approach implements market innovations to establish a presence in foreign markets and to move the product or service up the value chain. The second approach uses the funding to de-risk workforce expansion and increase production capacity.

Originality/value: The paper provides the first systematic disaggregate level analysis of an early post-accession context where impacts of EU support for SME innovation are decomposed into effects of specific investment conditions and innovation type on changes in capital base, employment, unit price and ultimately revenue. The insights provided here are valuable for managers developing business and innovation strategies on the one hand, but also for policy-makers responsible for creating an entrepreneurship-friendly environment in emerging economies.

Keywords: innovation, small to medium sized enterprises, entrepreneurship, official support bodies

Article Classification: Research Paper. JEL: D22, L26, O32 


\section{Factors affecting outcomes of EU-supported investments in innovation among SMEs in the Greater Poland (Wielkopolska) region, Poland}

\section{Introduction}

The European Union's strategy for supporting small and medium sized enterprises (SMEs) includes trade liberalisation, harmonisation of regulations, promotion of fair competition, simplification of fiscal and regulatory systems, as well as financial support for investment-, innovation-, and exportoriented activities (European Commission, 2008). To implement these approaches, the EU makes use of various policy tools, including tax exemptions, financial aid, public investment programmes, the development and transfer of technologies, training schemes and the creation of information and knowledge networks. These initiatives are aimed at creating a coherent and supportive environment for the SME sector, and are funded through multi-year programmes, including Framework Programmes for Research and Technological Development, European Investment Funds, European Social Funds, as well as Structural Funds (European Commission, 2014).

The significance of supporting SMEs rests on their contribution to national economies. Tarute et al. (2014) pointed out that SMEs constituted more than $90 \%$ per cent of all companies in developed countries, enjoying growth rates higher than large companies and also employing the majority of the labour force. Increasingly, however, the growth of SMEs has become dependent on the ability to innovate. Consequently, knowledge and experience regarding the utilisation of innovationsupporting funding have become more valuable. Such knowledge can assist SMEs in their business planning and thus lead to higher chances of successfully investing in innovation (Radas et al., 2009; Rosenbusch et al., 2011). The Polish context, in which this paper is placed, is a valuable setting for analysing the impacts of innovation support for SMEs under the conditions of a catching up, postsocialist economy. The country's SME sector proved instrumental following Poland's transition to the free market system in 1989, especially by providing employment opportunities for those made redundant during the restructuration of inefficient state-owned enterprises. At that time, however, a lack of access to suitable financing and support mechanisms meant that many such companies struggled to innovate, and were often unable to realise their full growth potential (Markovic et al., 2011).

The accession of Poland to the EU in 2004 radically changed this landscape since the SME sector could start to benefit fully from the EU's support mechanisms. This support has been seen as one of the ways to accelerate convergence between the 'old' and 'new' countries (MID, 2013). A shortage of knowledge regarding how to obtain and, more importantly, utilise the EU funding successfully, however, has been identified as one of the main reasons for the relatively poor performance of Polish enterprises with regards to translating innovation into commercial success (Klonowski, 2012). This shortage of knowledge was caused partly by the fact that the existing expertise and guidance relied primarily on experiences and studies from more mature market economies, with conditions often very different from those of the newly joining states (Radas et al., 2009; Romero-Martínez et al., 2010). However, Polish SMEs have tended initially to concentrate their efforts on capital investment and import of foreign technology, rather than indigenous innovation (Breznitz and Ornston, 2017). Understanding factors that enable successful achievement of the latter is, however, key for enraging ongoing productivity growth and escaping middle income trap.

In the past decade researchers have started to address this gap in knowledge, and the present paper seeks to contribute to this strand of research through an analysis of 110 SMEs from the Greater Poland (Wielkopolska) region in Western Poland who successfully obtained EU support for their investments in innovation during the early post-accession years, i.e. 2006 to 2008. Five groups of factors ${ }^{1}$ are analysed: funding availability, innovation type, investment purpose, location,

\footnotetext{
${ }^{1}$ In the present context the phrase factor is used interchangeably with conditions and circumstances.
} 
company attributes, which predisposed their EU-supported investment in innovation to lead to growth in revenue. Structural equation modelling (SEM) is used to decompose interrelationships between these factors and changes in the employment level, the capital base, the unit price and the revenue. This approach complements the existing literature by offering a systematic disaggregate analysis of in the context of early post-accession Poland, to date absent from the field. The geographically narrow focus is beneficial in light of findings of Bruton et al. (2014) who suggested that no single, ideal model for entrepreneurial firms exist. Hence insights provided here are valuable for managers developing business and innovation strategies on the one hand, but also for policymakers responsible for creating an entrepreneurship-friendly environment in emerging economies.

The structure of the paper is as follows. Section 2 discusses findings from previous studies exploring factors associated with higher chances of an investment in innovation being successful. This knowledge provide a means of constructing, in section 3, a methodology in the form of a conceptual model of how innovation investment conditions influence the performance of a company. In section 4 empirical data and SEM operationalisation is presented. Section 5 discusses the findings while section 6 draws conclusions and presents suggestions for future research.

\section{Previous research on factors influencing the effects of investments in innovation in the SME sector}

The literature overview below presents existing studies on how the particular circumstances in which investment in innovation took place were associated with the growth of the innovating companies. The specific findings reported in each of the five groups of factors (innovation type, investment purpose, funding type and financial readiness of the companies, location and collaboration possibilities, company size and sector of operation) provide a rationale for the subsequent inclusion of these factors in the conceptual model and empirical analysis.

\subsection{Innovation type}

The most widely recognised taxonomy of innovation was suggested by Schumpeter (1943) who distinguished four types of innovation: process, product, organisation and market. Since then, this distinction has helped researchers to explore systematically and comparatively the effects of implementing these different types of innovation.

In terms of empirical research, Gunday et al. (2011) reported that all types of innovation have a positive influence in terms of improving the performance of SMEs. A similar set of findings was reported by Rosenbusch et al. (2011) who also noted that innovation had positive effects on the performance of the businesses, the relative returns on investing resources in different types of innovation (e.g. process and output) were different. Varis et al. (2010) provided evidence from Finland that the introduction of product and market was associated with company growth. Oke et al. (2007), meanwhile, noted that incremental rather than radical innovations appeared to be more costeffective. Hall et al. (2009) provided evidence for the significant role of product and process innovation in improving the productivity of the SMEs. A similar finding was reported by Laforet (2013), although in relation to organisational innovation. They also noted the latter's association with increased margins, greater market leadership, and improved working environments, but not operational efficiency or employees' retention. Radas et al. (2009) looked at the SME sector in Croatia, concluding that product and process innovations were more likely to be associated with a company's expansion in both national and international markets.

Zapalska et al. (2015), working in the context of Polish tourism industry, demonstrated importance of organisation innovation, noting the role of suitable leadership style and communication, in ensuring company's growth and successful implementation of other types of innovation. Lewandowska et al. (2016) conducted a research using 6,855 Polish firms and examined complementarities between various types of innovation: product, process, and marketing innovations. They concluded that combining product and process innovation resulted in increased export intensity. 
A more critical perspective was presented by Hoffman et al. (1998) who presented ambiguous results regarding the effects of innovation on company performance. They noted, however, the existence of substantial evidence for employment growth among expanding SMEs, although that evidence was questioned by other researchers at that time. On the other hand, Mazur and Zaborek (2016) indicated that organisation innovation in the form of so-called innovative culture, i.e. fostering creativity and inter-employee cooperation, had no direct effect on sales but improved operational performance and overall company efficiency.

\subsection{Investment purpose}

Another group of studies explored the associations between the expansion of companies and the purposes of the investment they undertook. One of the most important reasons for innovation is research and development (R\&D) activities. Looking at those, Dmirel et al. (2012) and Piras et al. (2012) indicated that R\&D activities tended to be associated with company growth, further reflected in the higher survival rates (Lee et al., 2015). Karhunen et al. (2015) provided evidence for a growth in employment among companies undertaking more R\&D activities, and a number of other studies have indicated a positive association with output and productivity (Doraszelski et al., 2013; Hall et al., 2009).

Conversely, Bottazzi et al. (2002) demonstrated that companies with a high expenditure on R\&D and seeking international expansion would not necessarily seek to increase the level of employment. Hall et al. (2009) found that competing internationally encouraged R\&D, which in turn was associated with a higher likelihood of process and product innovations, ultimately resulting in higher productivity. In addition, Moen et al. (2016) reported that an international orientation tended to be linked to a stronger focus on growth, thus leading to a better performance, which the authors attributed to the existence of a managerial practice of seeking to expand into new markets. In the Polish context, the importance of internal culture, communication and organisation was highlighted by Norek (2013) who indicated those as primary barriers to successful innovation activities by Polish SMEs.

A different stream of research looks at investment in information and communication technologies (ICT), often to stimulate organisational and process innovation. Studies reported that improvements in productivity resulting from the use of ICT by companies could amount to $30 \%$, depending on context and technology (Becchett et al., 2003; Grimes et al., 2011). Based on a sample of Spanish companies, Díaz-Chao et al. (2015) reported that investment in ICT could lead to increased innovativeness and thus higher exporting potential and labour productivity, especially in companies with flexible remuneration practices. In the Polish context, Kmieciak et al. (2012) found the performance of company to be positively related to ICT knowledge and innovation activities in the companies, the latter also influenced by level of investment in ICT.

Tarute et al. (2014), having reviewed a number of studies on the role of ICT adoption in SMEs productivity, concluded that such technologies could improve the financial and operational performance of companies, especially through increased productivity, profitability, market value, market share and resource allocation, as well as better internal and external communication. Kossaï et al. (2014) argued, nevertheless, that introduction of ICT needed to be accompanied by suitable organisational changes, such as training or decentralised decision-making protocols, in order fully to utilise their potential to contribute to the long-term growth of a company (Martin et al. 2013).

\subsection{Funding availability and financial readiness}

Another group of factors of potential relevance describe the financial circumstances in which investment is taking place. In particular we explore the role of type of financial support (funding), and the company's financial readiness to undertake the investment if funding was not available to them (the latter being a net effect of the financial capacity of the company as well as perceived risk of the investment).

Hoffman et al. (1998) pointed towards the availability of funding being an important factor determining an investment's success. At the time of publication they were unable to state, however, 
which form of financial support proved the most effective and under what circumstances. In addition, they also emphasised the need for a supportive policy environment for companies undertaking investment in innovation, and in the subsequent commercialisation of that innovation. Similar points were raised by Breznitz and Ornston (2017) who provided the example of Finland and Israel, where long-term and consistent funding for R\&D and innovation from starting in 1970s had managed to transform countries into knowledge-intensive economies.

In their empirical study of Dutch companies, Keizer et al. (2002) found innovation subsidies to be important determinants of the extent and magnitude of the innovative efforts. The authors did not, however, report on any role for the financial readiness of the company. Radas et al. (2009), following a similar approach to that of Keizer et al. (2002), analysed the factors influencing the propensity to innovate among Croatian enterprises. While noting numerous similarities between the Croatian and Dutch SME sectors, the authors did not find the association between the presence of subsidies for innovation and the innovativeness of companies to be significant.

In the Polish context, Karpińska-Mizielińska et al. (2009) noted that SMEs utilising the EU support tended to have higher employment and revenue levels, in addition to exporting more and devoting more resources to investment. In addition, they noted an overall consensus among the surveyed companies that the availability of the funding improved their competitiveness, which was especially reflected in higher numbers of customers. They noted, however, that successful investments, i.e. leading to company's growth, tended to be primarily those which the companies would have undertaken even if the support had not been obtained. Also in the Polish context, Czerniak and Stefański (2016) argued that proportion of companies investing in R\&D among companies with access to external funding was almost $10 \%$ higher as compared to those without such access.

Another perspective was presented by Heimonen (2012) and Lee et al. (2015) who concluded that the innovative ones would normally face more financial pressures, thus presenting a clear rationale for public support in order to achieve innovativeness and growth. An interesting point was also made by Mason et al. (2010) who suggested that not only financial, but also procedural readiness to undertake an investment were important determinants of success in the subsequent acquisition of further support, and in the company's growth.

\subsection{Location and collaboration}

Another factor of potential importance is the location of the company, especially in relation to the potential market, various infrastructure and facilities, or the resource base, among others (Heimonen, 2012). Kaufmann et al. (2002) and Adekola et al. (2008) noted that the crucial preconditions for the SME support to be effective in stimulating their growth, was the availability of suitably qualified manpower. They emphasised, therefore, the potential difficulty for that condition to be met in relatively poorer regions, which also tended to suffer more from 'the brain drain', and where consequently innovation-supporting initiatives could be hampered. Similarly, Hoffman et al (1998) pointed to the importance of the availability of suitably qualified scientists and engineers, who could form the key sources of innovation in companies. Interestingly, they also argued that, based on the UK data, rural enterprises tended to be more innovative as compared to their urban counterparts, although they did not explore this finding in detail. It should be noted, however, that their review was published in the late 1990s, and thus prior to the emergence of the digitallyoriented urban-based start-ups which currently constitute one of the main engines of innovation.

Keizer et al. (2002) provided evidence for the importance of links to knowledge centres in improving the innovative efforts of companies. In addition, Beck et al. (2006) suggested that an SME-friendly and competitive business environment was an important facilitator in the entry exit, and growth of companies. Breznitz and Ornston (2017) used the examples of Finland and Israel to emphasise the importance of collaboration between various stakeholders in innovation ecosystem, including SMEs, R\&D institutions, universities, public sector and large industry as well as coordinated policy-making aimed at reforming other sectors such as education, tax policy or risk capital markets. The later point was also made by Bruton et al. (2014) who found the institutional 
and policy setting to be strongly reflected in companies' management dynamics, and thus their overall strategy. Similarly, in the Polish context Nowacki and Staniewski (2012) pointed towards a limited access to knowledge about innovation due to poor collaboration with expert centres as a barrier to effective innovation. In a similar manner, Jankowska (2015) indicated that collaboration could serve as a way of internationalisation and growth, as cluster organisations could facilitate foreign market entry, otherwise difficult to achieve on their own by smaller companies.

\subsection{Company size and sector}

The final set of factors include attributes of the company itself, specifically its size (and hence scale) and sector of operation. Beck et al. (2006) noted that smaller firms tended to face more obstacles when obtaining funding for their investments, which placed them at a more disadvantaged position compared to larger companies. Nevertheless, Lee et al. (2015) demonstrated that it was actually small and micro companies that were more likely to apply for funding, although the authors did not report on how this affected their subsequent performance. The latter was explored by Hall et al. (2009), however, who analysed a sample of Italian SMEs and found that larger and older SMEs were in general less productive. Working in a Polish context, Kowalski (2009) reported that medium-sized companies experienced the highest increase in employment from EU-supported investments. Heimonen (2012), using a sample of companies from Finland, identified small companies, i.e. between 10 and 49 employees, as the most innovative.

Regarding the impact of operating in a specific sector, Jones-Evans et al. (1996) pointed towards technology-based businesses as displaying the most growth in revenue and employment. This was also supported by findings from Agarwal et al. (2001) who quoted technology-based startups as having higher survival rates than non-technological ones. Hoffman et al. (1998) indicated that biotechnological companies, especially those located in science parks, performed comparatively better.

\section{Methodology}

In order to investigate quantitatively how the different conditions introduced above predisposed particular investments in innovation to support companies' growth, the following conceptual framework is proposed (Figure 1). This framework seeks to jointly capture these relationships through changes in employment, capital and unit price.

--- FIGURE 1 ---

The framework is based on the classical microeconomic representation of companies whereby revenue is a function of labour and capital inputs and technology is used to combine these inputs, as well as the price of the goods and services offered. In this framework, an investment in innovation can affect the company's revenue through changes in the inputs and unit price. A number of factors can, however, affect the direction and relative magnitudes of these specific changes, as outlined in section 2. In this paper a number of such factors are explored (see Table 1). The conceptual representation thus incorporates elements of the heuristic proposed by Edwards et al. (2005), where the current exogenous variables serve as proxy variables for the 'innovative potential' while the endogenous variables describe the performance of the company.

The model accounts also for the possibility that changes in the labour and capital inputs are motivated by the company's strategy to change its product and service price, for example, to achieve higher market penetration by lowering the unit price. This is captured by the vertical arrows between the employment, capital and price change components.

The framework above is operationalised using the structural equation modelling (SEM) technique. SEM conveniently allows the incorporation of multiple simultaneous relationships between variables, and the estimation of the correlations between them implied by the covariance matrix observed in the sample. SEM has been used in similar studies in the field, e.g. Gunday et al. (2011) or Díaz-Chao et al. (2015). In the current paper, the SEM is estimated using the diagonally 
weighted least squares (DWLS) approach relying on polychoric correlations (Rhemtulla et al., 2012) in order to account for the limited sample size and discrete nature of the variables. The estimation was carried out using the 'lavaan' package (version 0.5-18) for the R environment (Rossel, 2012).

\section{--- TABLE 1 HERE ---}

\section{Data}

The model is estimated using data collected in the Greater Poland (Wielkopolska) region (voivodship) by means of a questionnaire survey. The region has traditionally been characterised by one of the highest SME entrepreneurship rates in Poland. In 2006, the final year of the funding period under investigation, there were almost 350,000 companies in the region but only 482 of these had 250 employees or more. While the population of the voivodship was less than $9 \%$ per cent of the country's total, its share of companies was $9.6 \%$ for micro, $9.9 \%$ for small, and $10.8 \%$ for medium ones respectively. In addition, the region has consistently been indicated as one of the most efficient in absorbing the pre-allocated EU funds (Kwieciński et al., 2013), hence making it a useful place in which to conduct the proposed research.

The survey questionnaires were posted in 2008 to all SMEs in the Greater Poland region that received funding from the Sectoral Operational Programme - Improvement of Competitiveness of Enterprises (SOP-ICE) Priority 2 in the period 2004-06. The primary objective of the programme was to improve the competitiveness of Polish economy in the free-market environment (MRD, 2006, p. 86). The suitable SMEs were identified through a publicly available list of funding recipients obtained from the Polish Agency for Enterprise Development (PARP), which is the government body managing national and EU funding allocation and distribution to the SMEs. As a result, 242 companies were contacted and sent a questionnaire, which consisted of six parts covering the following aspects of funding use (recall Table 1 for a more detailed list of questions and the format of reporting):

- investment purpose;

- type of innovation implemented as a result of the investment;

- the company's previous experience in applying for and using the EU support mechanisms;

- funding and financial readiness;

- results of the investment, including changes in capital base, employment, unit price, and revenue;

- company location and collaboration;

- company size and sector of operation.

Out of the total 242 companies, 174 returned the questionnaire. 110 questionnaires were sufficiently complete and logically coherent to be included in the final analysis, thus yielding an effective response rate of $45.4 \%$. The sample size is comparable to studies on innovation in SMEs conducted elsewhere, e.g. Kmieciak et al. (2012) or Codogni et al. (2017). Table 2 provides a number of descriptive statistics in respect to this final sample, subsequently used in the SEM analysis.

\section{--- TABLE 2 HERE ---}

Among the investigated companies, 53 were either micro or small (up to 50 employees) with the remaining 57 being medium-sized enterprises. The majority of the companies reported revenue above 1,000,000 PLN in 2007 (about €263,000), were located in urban areas, and operated in either the manufacturing or service sectors. Most companies had previous experience in using the SOPICE funding, with a large proportion also having experience in using the pre-accession fund PHARE (Poland and Hungary: Assistance for Restructuring their Economies). Only $14.5 \%$ of companies had no prior experience in using EU funding. The survey sample was drawn from 
companies already known to receive SOP-ICE funding, but in addition almost all (99.1\%) applied for the SOP-ICE partial objective 2.3, i.e. increased competitiveness via investment. Process and product innovations were the most prevailing reasons for seeking this funding, at $69.1 \%$ and $72.7 \%$ respectively, but organisational and marketing innovations were implemented much less frequently, at $20 \%$ and $4.5 \%$ respectively. Most of the companies invested in order to increase their competitiveness both nationally (76.4\%) and internationally (50\%). Quality improvements and the development of an export strategy were also important, with $62.7 \%$ and $21.8 \%$ of companies, respectively, reporting such an investment purpose.

\section{Findings}

The model estimation results are summarised in Table 3. The overall root-mean-square-error of approximation (RMSEA) is below the benchmark 0.08, indicating a low discrepancy between the observed and model-implied covariance matrices (Hooper et al., 2008). This is also confirmed by the other fit indices (CFI, NFI, and GFI) with the values above the benchmark of 0.95 . Hence the achieved goodness-of-fit is acceptable. The sections below present the specific results concerning the endogenous and exogenous variables, followed by a synthesising discussion.

\section{--- TABLE 3 HERE --}

\subsection{The endogenous variables: labour, capital and price}

The relationships between the endogenous variables reflect how changes in the inputs or unit price were correlated with changes in revenue. In microeconomic terms, this reflects the technology of production. In the sample, only the changes in employment are positively correlated with the reported change in the level of revenue. Pokorski (2010) noted that one of the aims of SOP-ICE programme was to ensure an increase in employment by SMEs. In that respect the programme was successful with, on average, $11 \%$ increase in employment among supported companies. No effect on revenue from a change in the capital base or unit price is observed. In other words, the growth in revenue resulting from investment in innovation tended to result more from the hiring of new employees rather than from capital base expansion or changes in unit pricing which is also echoed in the findings of Czerniak and Stefański (2016). This can indicate that the funding support served as an instrument to de-risk the expansion of production through increased employment. The results suggest that this expansion is an important driver of revenue growth. There is, however, the possibility of a bi-directional interaction, where the revenue growth is taken by a company as a promising signal of the success of the investment, encouraging employment expansion.

Similar relationships in relation to changes in the capital base or unit price are not observed. In other words, changes in the capital base or employment do not tend to be reflected in changes in the unit price. It is possible, however, that instead of looking at the unit price, the companies could aim to change (reduce) the unit cost to increase their profitability. This interpretation would also be consistent with the SME sector being primarily price-taking, and for whom streamlining and cost reduction is normally a less risky strategy than price competition. In fact, price competition has been seen as an ongoing, primary competitive advantage of Polish SMEs as compared to their European counterparts (PARP, 2015, 2016).

\subsection{The exogenous variables}

\subsubsection{Innovation type}

Regarding the effects of the type of innovation implemented, the findings point towards this being of a lesser importance in determining market performance compared to the findings of Rosenbusch et al. (2011) or Gunday et al. (2011). Charucka (2014) indicated that almost $40 \%$ of companies at that time did not see benefits in innovation whilst $37 \%$ would see themselves as too small to innovate. The only statistically significant results are a negative correlation between marketing 
innovation and changes in the capital base, and a positive correlation between marketing innovation and changes in the unit price. This finding indicates that companies focused on marketing innovations are less likely to engage in capital base expansion. This is largely consistent with the fact that during the survey period, access to support mechanisms for capital base expansion for the SME sector in Poland was still in its infancy. The only viable alternative was, therefore, to develop market strategies that sought to position products and services higher in the value chain. Such efforts were primarily aimed at increasing the value-added and thus to target more demanding and increasingly more affluent customers. This interpretation is supported by findings of StarczewskaKrzysztoszek (2011) who noted that in the local, regional, and national market Polish SMEs tended to compete primarily by means of quality and value improvement.

At the same time, investments in other types of innovation are not found to have statistically significant associations with changes in the production inputs or unit price. A possible explanation for this result is a high prevalence of these innovation types in the sample (recall Table 2), and hence limited variation. In other words, process, product and organisational innovations seem to be present in these companies regardless of changes in the capital base or employment. This finding emphasises that future studies require a much more in-depth understanding of the exact nature of the innovation investments that goes beyond the 4-type distinction.

\subsubsection{Investment purpose}

Regarding the investment purpose, a negative correlation between seeking to improve competitiveness in international markets and likelihood of changes in the capital base is observed. When interpreted in conjunction with the positive association between marketing innovation and unit price change, this can indicate that companies have sought to establish themselves in foreign markets within their existing production capacity, and to thus to innovate in respect to their target markets. For such companies, expansion in terms of capital and labour would be expected only following their successful establishment in a foreign market. This interpretation can also explain why the initiation of or an increase in exporting lack significant associations. Moreover, such an effect is not observed in the case of national competitiveness, where the company is, arguably, more aware of the local conditions and can therefore scale its operations more accurately and flexibly. An explanation to this finding is offered by Pokorski (2010) who pointed out that funding available as part of SOP-ICE 2.3 (which was the primary mechanism in the current sample) enabled the SMEs to become more competitive mainly in local, regional, and national markets. This was achieved by improvement of quality in the products and services and increased capacity. Last but not least, Jankowska (2015) pointed out that internationalisation of Polish SME has not been very intense in terms of sophistication of exporting activities, identifying this as a potential obstacle in long-term development of exporting capability.

No significant association between the purpose of investment being an improvement in the quality of goods or services and changes in the input factors is observed. This is unsurprising since SMEs would typically seek to improve the quality within their existing pools of resources through modifications of existing practices, rather than by altering the scale of production.

Neither is any significant relationship associated with investments in ICT observed. Such investments could include both capital base expansion, e.g. increased automation, equipment monitoring, and change to employment, e.g. hiring skilled workers, introduction of remote work practices. This can be a consequence of the relative immaturity of the SME sector at the time of the survey. This immaturity would translate into a lack of the necessary scale of adoption, which is crucial in achieving the full range of benefits enabled by ICT, or insufficient skills and organisational capacity to implement the ICT-based organisational changes (Kossai et al., 2014; Martin et al., 2013). In fact, the lack of digitally-skilled personnel has been identified as being an ongoing issue with successful implementation of ICT among Polish SMEs. For example, only 10\% of Polish SMEs employ a dedicated ICT specialist as compared to 20\% EU average (PARP, 2017). 


\subsubsection{Funding availability and financial readiness}

As far as the funding is concerned, the use of SOP-ICE 2.3 is associated with a higher likelihood of seeking to increase the capital base. On the other hand, the relationship between the experience of having used SOP funding in the past and capital base expansion is negative. This can be interpreted in light of the findings of Pokorski (2010) who emphasised the role of SOP-ICE in addressing the shortage of capital base among SMEs prior to 2004 which had been a substantial barrier to SME sector growth.

Regarding the financial readiness, while the self-funded proportion of the investment does not display a significant association with the endogenous variables, the independent investment readiness is strongly positively correlated with change in employment. All these results jointly indicate the existence of companies who had already invested in the past, especially in capital base expansion, and are now using the EU funding as a means of enabling their workforce expansion. This is an important implication showing that SMEs which are mature enough to commit to investments regardless of the availability of external support, are also more likely to be the source of employment and, ultimately, revenue growth. This also confirms findings of Czerniak and Stefański (2016) pointed out that internal resources have remained by far the primary means of financing innovation, and in fact more general investments among Polish SMEs.

The finding above implies that in the context of supporting innovation among SMEs, external support to that sector in the form of EU funding could offer a means of facilitating growth in employment and the economy overall. Such evidence is especially important following the economic crisis which made it even more difficult for SMEs to obtain funding for innovative but also riskier investments (Lee et al., 2015). The findings are in this respect in line with the results reported in recent years (Beck et al., 2006; Heimonen, 2012; Lee et al., 2015).

\subsubsection{Location and collaboration}

Regarding the role of location, no specific effects associated with a company being located in urban areas, or operating in a particular sector are observed. In that sense, the findings only partially support that of Laforet (2013) who reported on the role of both factors.

In addition, no evidence is found in relation to the role of being a technology co-creator in collaboration with an R\&D institutions. It is possible that technologies involved in such investments tend to be at such an early stage that companies would be prevented from scaling their production until their effectiveness was proven. Similarly, the fact that a particular investment took place in an industrial or technological park, or enterprise incubator, could also indicate a lack of the necessary maturity for a company to commit to altering its production process. The lack of significant effect could be partly explained by findings by Breznitz and Ornston (2017) who reported on effectiveness of the support reported in the follow-up 2007-20013 period in Poland, which could simply reflect a longer lag between investment in an early R\&D and its impact on company's performance. It is also possible that these factors had an effect on the willingness to undertake innovation in the first place, rather than on the actual result of the investment, as suggested in the literature (Keizer et al., 2002; Radas et al., 2009) although, unfortunately, the present data does not permit testing this hypothesis.

\subsubsection{Company size and sector}

In terms of the sector of operation, no significant associations with the inputs or unit price is statistically significant. This is in contrast to findings reported by Pokorski (2010) who indicated industrial sector SMEs as benefitting more as compared to services or commerce. Finally, in terms of a company's attributes, the medium-sized companies are observed to be more willing to increase their employment, but less so to increase their capital base. This finding is consistent with that of the aforementioned study by Kowalski (2009), also in the Polish context. It thus appears that medium-sized companies are focused more on the human capital-side of production which can also reflect their possession of a more substantial capital base, now requiring the commensurate labour input. 


\section{Conclusions and further research directions}

The importance of analysing the conditions which are associated with successful investments in innovation in the SME sector results from the sector's growing role as a source of economic growth. The role of supporting innovative investments in the SME sector is especially important for countries that have undergone transformations to a market-based economic model relatively recently, including Poland and other countries of Central and Eastern Europe. These countries seek to advance their enterprises to high levels of technology and innovation through the most effective use of various EU funding mechanisms.

In the current analysis of 110 SMEs from the Greater Poland (Wielkopolska) region, a simple conceptual model of how the conditions in which EU-supported investment in innovation takes place may affect changes in the production factors (labour, capital), price, and ultimately the revenue. This framework delivers novel insights into how SMEs make use of the EU funding. Specifically, two different strategies for using the available funding are observed, although not necessarily mutually exclusive. The first approach utilises the funding to implement innovate in respect to the target market, often by establishing a presence in foreign markets, and moving the product up in the value chain. The second approach, more prevalent among medium-sized companies, uses the funding to expand the workforce so as to increase utilisation of the existing capital base, and hence the overall production capacity. The findings are largely consistent with observations and analyses conducted elsewhere although, to the best of the authors' knowledge, the present contribution represents the first attempt to analyse them in a single conceptual and econometric framework of SEM.

The results above contribute towards a better understanding of how the EU funding support for innovation in the SME sector can translate into employment and revenue growth. The findings can hence aid more effective policy design, especially in terms of more accurate forecasting of the subsequent micro- and macroeconomic implications. An especially interesting aspect of this concerns implications for the labour market, given that the results point towards a positive link between employment and the innovativeness of small enterprises. This naturally raises a question as to which occupations and skills may become more demanded as the SME sector becomes more and more innovation-oriented. Clearly, in the case of Polish SMEs there remains a gap with respect to skills of the labour force, e.g. in ICT use. Thus to realise the full potential of SME sector in Poland, it is urgent to increase efforts towards improving high-value skills of employees, both in terms of those demanded in the growing knowledge economy as well as in the high value-added industrial sector. An aligned education system and training programmes as well as closer collaboration between industry and educational institutions could offer an efficient way forward.

Another important implication emerging from the findings relates to the issue of access to suitable funding for small and medium enterprises to undertake investment in innovation. If the ongoing efforts towards integration of financial markets and the creation of a capital markets union (CMU) lead to greater availability of such funding, the findings can suggest positive implications for the labour market. This is particularly important in the case of Polish SMEs where access to suitable funding has remained an ongoing issue in successful implementation of innovation, and thus their long term growth and scaling.

From the managerial point of view, the results deliver useful insights for SMEs operating in conditions of economic transformation similar to those of Poland's, and other 2004 EU accession countries. The most important implication concerns the need to recognise the vital role of investments in innovation but also their multifaceted nature, and their consequences. The two distinct approaches to innovation by companies revealed in the analysis indicate that there is not a single, fit-for-all approach to investing in innovation. Instead, entrepreneurs and managers usually need tailored approaches and flexibility in using mechanisms of support specific to their context, the available resources (both human and capital) and the conditions of the sector.

Naturally, the findings presented in this paper are subject to a number of limitations. Firstly, they must be interpreted bearing in mind the specific context following Poland's accession to the 
EU. The funding available at that time was focused primarily on strengthening SME sector characterised by relatively poor capital base, lack of technological advancement, and with very limited options for financing capital base expansion. Secondly, the set of exogenous variables was limited and in future research, could be expanded to include more detailed information about the companies (e.g. skills of the employees), use of external expertise when seeking funding, the innovation implemented or macroeconomic conditions prevailing in the sector, region or country. We also note that availability of a larger sample would increase statistical power of the analysis. In addition, the specificity of the companies in both a geographical and temporal sense means that the conclusions drawn here may not hold in other contexts. On the other hand, carrying out similar analyses across countries and time, and involving more harmonised datasets could shed light on the extent to which certain patterns prevail internationally and how they evolve over time. 


\section{References}

Adekola, A., Korsakiene, R., Tvaronavičiene, M. (2008), “Approach to innovative activities by Lithuanian companies in the current conditions of development", Ukio Technologinis ir Ekonominis Vystymas, Vol. 14, pp. 595-611.

Agarwal, R. and Audretsch, D.B. (2001), "Does entry size matter? The impact of the life cycle and technology on firm survival", The Journal of Industrial Economics, Vol. 49, pp. 21-43.

Becchetti, L., Bedoya, D.A.L. and Paganetto, L. (2003), "ICT investment, productivity and efficiency: Evidence at firm level using a stochastic frontier approach", Journal of Productivity Analysis, Vol. 20, pp. 143-167.

Beck, T. and Demirguc-Kunt, A. (2006), "Small and medium-size enterprises: Access to finance as a growth constraint", Journal of Banking and Finance, Vol. 30, pp. 2931-2943.

Bottazzi, L. and Da Rin, M. (2002), "Venture capital in Europe and the financing of innovative companies", Economic Policy, Vol. 17, pp. 229-270.

Breznitz, D. and Ornston, D. (2017) "EU financing and innovation in Poland", European Bank for Reconstruction and Development Working Paper No.198.

Bruton, G., Lau, C. and Obloj, K. (2014), "Institutions, resources and firm strategies: a comparative analysis of entrepreneurial firms in three transitional economies", European Journal of International Management, Vol. 8(6), pp. 697-720.

Codogni, M., Duda, J. and Kusa, R. (2017), "Entrepreneurial orientation in high-tech and low-tech SMEs in Malopolska region", Managerial Economics, Vol. 18(1), pp. 7-22.

Charucka, O. (2014), "Kluczowe czynniki konkurencyjności MSP i ich wpływ na rozwój gospodarki" [Key factors affecting competitiveness of SME and their impact on economic growth], Zeszyty Naukowe Uczelni Vistula, Vol. 35, pp. 45-67.

Czerniak, A. and Stefański, M. (2016) "Small and medium enterprises in Poland - obstacles and development", report by Polityka Insight Research, available at:

https://www.politykainsight.pl/multimedia/_resource/res/20105186 (accessed 01 October 2017).

Demirel, P. and Mazzucato, M. (2012), "Innovation and firm growth: Is R\&D worth it?", Industry and Innovation, Vol. 19, pp. 45-62.

Díaz-Chao, Á., Sainz-González, J. and Torrent-Sellens, J. (2015), "ICT, innovation, and firm productivity: New evidence from small local firms", Journal of Business Research, Vol. 68, pp. 1439-1444.

Doraszelski, U. and Jaumandreu, J., (2013), "R\&D and productivity: Estimating endogenous productivity", The Review of Economic Studies, Vol. 80, pp. 1338-1383.

European Commission (2008), "Think Small First: A Small Business Act for Europe" available at: http://ec.europa.eu/growth/smes/business-friendly-environment/small-business-act/index_en.htm (accessed 23 April 2016).

European Commission (2014) “The Multi-annual Financial Framework 2014-2020”, available at: http://ec.europa.eu/clima/policies/adaptation/financing/funds/index_en.htm (accessed 05 May 2016).

Grimes, A., Ren, C., and Stevens, P. (2011), "The need for speed: impacts of Internet connectivity on firm productivity", Journal of Productivity Analysis, Vol. 37, pp. 187-201.

Gunday, G., Ulusoy, G., Kilic, K. and Alpkan, L. (2011), "Effects of innovation types on firm performance", International Journal of Production Economics, Vol. 133, pp. 662-676.

Hall, B. H., Lotti, F., and Mairesse, J. (2009), "Innovation and productivity in SMEs: empirical evidence for Italy", Small Business Economics, 33, pp. 13-33.

Heimonen, T. (2012), "What are the factors that affect innovation in growing SMEs?", European Journal of Innovation Management, Vol. 15, pp. 122-144.

Hoffman K., Parejo, M., Bessant, J. and Perren, L. (1998), "Small firms, R\&D, technology, and innovation in the UK: a literature review", Technovation, Vol. 18, pp. 39-55. 
Hooper, D., Coughlan, J., and Mullen, M. R. (2008), "Structural Equation Modelling: guidelines for determining model fit", Electronic Journal of Business Research Methods, Vol. 6, 53-60.

Jankowska, B. (2015), "Cluster organization as a pro-internationalization form of cooperation in the SME sector - a Polish case in the European context", Journal of Economics and Management, Vol.22(4), pp. 54-74.

Jones-Evans, D. and Westhead, P, (1996), "The high technology small firm sector in the UK", International Journal of Entrepreneurial Behavior \& Research, Vol. 2, pp. 15-35.

Kamińska, A. (2010), "Programy pomocowe Unii Europejskiej jako źródło finansowania rozwoju i konkurencyjności sektora małych i średnich przedsiębiorstw" [EU support mechanisms as a source of financing of development and competitiveness of the SME sector], Barometr Regionalny, Vol. 20, pp. 56-69.

Karpińska-Mizielińska W., Smuga T., and Echaust M (2009), "Wpływ pomocy z funduszy strukturalnych na konkurencyjność przedsiębiorstw" [Structural funds and their influence on the competitiveness of enterprises], Gospodarka Narodowa, Vol. 1-2, pp. 89-120.

Karhunen, H. and Huovari, J. (2015), "R\&D subsidies and productivity in SMEs", Small Business Economics, Vol. 45, pp. 805-823.

Kaufmann, A., and Tödtling, F. (2002), "How effective is innovation support for SMEs? An analysis of the region of Upper Austria", Technovation, Vol. 22, pp. 147-159.

Keizer, J., Dijstra, L., and Halman, J.I.M. (2002), "Explaining innovative efforts of SMEs in the mechanical and electrical engineering sector in The Netherlands", Technovation, Vol. 22, pp. 113.

Klonowski, D. (2012), "Innovation propensity of the SME sector in emerging markets: evidence from Poland", Post-communist economies, Vol. 24, pp. 133-143.

Kmieciak, R., Michna, A., Meczynska, A. (2012), "Innovativeness, empowerment and IT capability: evidence from SMEs", Industrial Management \& Data Systems, Vol. 112(5), pp.707728.

Kossaï, M., and Piget, P. (2014), “Adoption of Information and Communication Technology and firm profitability: Empirical evidence from Tunisian SMEs", The Journal of High Technology Management Research, Vol. 25, pp. 9-20.

Kowalski, S. (2009), “Źródła finansowania sektora małych i średnich przedsiębiorstw w Polsce z uwzględnienem funduszy strukturalnych UE" [Financing of small and medium enterprises in Poland including the EU Structural Funds], Zeszyty Naukowe SGGW - Ekonomika i Organizacja Gospodarki Żywnościowej, Vol. 7, pp. 162-163.

Kwieciński, J. and Adamik, P. (2013), Stan Wykorzystania Funduszy Europejskich: VII Raport [The Level of use of EU Funds: VII Report]. Warsaw: Business Centre Club.

Laforet, S. (2013), "Organizational innovation outcomes in SMEs: effects of age, size, and sector", Journal of World Business, Vol. 48, pp. 490-502.

Lee, N., Sameen, H., and Cowling, M. (2015), “Access to finance for innovative SMEs since the financial crisis", Research Policy, Vol. 44, pp. 370-380.

Lewandowska, M.S., Szymura-Tyc, M. and Gołębiowski, T. (2016), "Innovation complementarity, cooperation partners, and new product export: Evidence from Poland", Journal of Business Research, 69(9), pp. 3673-3681.

Markovic, M.R. and Kyaruzi, I.S. (2011), "Poland's integration with the European Union and its implication for small and medium scale enterprises." Markovic, M.R., Redzepagic, S. and Andrade, J. Serbia and the European Union: Economic Lessons from the New Member States, Vol. 1, Institute of Economic Sciences, Belgrade pp. 317-331.

Martin, F. M., Ciovica, L., and Cristescu, M. P. (2013), "Implications of human capital in the development of SMEs through the ICT adoption", Procedia Economics and Finance, Vol. 6, pp. 748-753.

Mason, C., and Kwok, J. (2010), "Investment readiness programmes and access to finance: a critical review of design issues”, Local Economy, Vol. 25, 269-292. 
Mazur, J. and Zaborek, P. (2016). "Organizational Culture and Open Innovation Performance in Small and Medium-sized Enterprises (SMEs) in Poland", International Journal of Management and Economics, 51(1), pp. 104-138.

MID (2013), "Ministry of Infrastructure and Development: About the European Funds", available at:

https://www.funduszeeuropejskie.gov.pl/English/Introduction/Strony/Introduction_to_European Funds.aspx (accessed 15 August 2016).

Moen, Ø., Heggeseth, A. G., and Lome, O. (2016), “The positive effect of motivation and international orientation on SME growth", Journal of Small Business Management, Vol. 54, pp. 659-678.

Mohl, P. and Hagen, T. (2010), "Do EU structural funds promote regional growth? New evidence from various panel data approaches", Regional Science and Urban Economics, Vol. 40, pp. 353365.

MRD (2006), Sectoral Operational Programme: Improvement of the Competitiveness of Enterprises, Years 2004-2006, Ministry of Regional Development of the Republic of Poland, Warsaw.

Norek, T. (2013), "Key barriers to the development of effective innovative activity of Polish SME companies", paper presented to Global Business \& Economics Anthology (GBEA) Conference 2013.

Nowacki, R. and Staniewski, M. (2012), "Innovation in the management of SMEs in the service sector in Poland", Amfiteatru Economic, Vol.14, pp. 755-773.

Oke, A., Burke, G., and Myers, A. (2007), "Innovation types and performance in growing UK SMEs", International Journal of Operations \& Production Management, Vol. 27, pp. 735 - 753.

PARP (2015), "Raport o stanie sektora małych i średnich przedsiębiorstw w Polsce w 2013-14" [State of the SME sector in Poland in 2013-14], available at https://badania.parp.gov.pl/images/badania/ROSS_2013_2014.pdf (accessed 02 October 2017).

PARP (2016), "Raport o stanie sektora małych i średnich przedsiębiorstw w Polsce w 2016" [State of the SME sector in Poland in 2016], available at https://www.parp.gov.pl/images/PARP_publications/pdf/2016_raport_msp_pl_clik.pdf (accessed 01 October 2017).

PARP (2017), "Raport o stanie sektora małych i średnich przedsiębiorstw w Polsce w 2017" [State of the SME sector in Poland in 2017], available at https://www.parp.gov.pl/images/PARP_publications/pdf/raport\%20o\%20stanie\%20sektora\%20 msp\%20w\%20polsce_2017.pdf (accessed 02 October 2017).

Piras, G., Postiglione, P. and Aroca, P. (2012), "Specialization, R\&D and productivity growth: evidence from EU regions", The Annals of Regional Science, Vol. 49, pp. 35-51.

Pokorski J. (2010) Ocena Instrumentów Wsparcia Bezpośredniego Przedsiębiorstw: Podsumowanie Wyników Ewaluacji Wybranych Działań SPO WKP. [Evaluation of the Instruments for Direct Support to Enterprises: Results of Evaluation of Selected SOP-ICE Activities]. Warsaw: PARP.

Radas, S. and Božić, L. (2009), "The antecedents of SME innovativeness in an emerging transition economy", Technovation, Vol. 29, pp. 438-450.

Rhemtulla, M., Brosseau-Liard, P. E., and Savalei, V. (2012), "When can categorical variables be treated as continuous? A comparison of robust continuous and categorical SEM estimation methods under suboptimal conditions", Psychological Methods, Vol. 17, pp. 354-373.

Romero-Martínez, A. M., Ortiz-de-Urbina-Criado, M., and Ribeiro Soriano, D. (2010), "Evaluating European Union support for innovation in Spanish small and medium enterprises", The Service Industries Journal, Vol. 30, pp. 671-683.

Rosenbusch, N., Brinckmann, J., and Bausch, A. (2011), "Is innovation always beneficial? A metaanalysis of the relationship between innovation and performance in SMEs", Journal of Business Venturing, Vol. 26, pp. 441-457. 
Rosseel, Y. (2012), 'lavaan: an R package for structural equations', Journal of Statistical Software, Vol. 48, No. 2, pp. 1-36.

Schumpeter, J. (1943), Capitalism, Socialism and Democracy. London: Allan and Unwin.

Starczewska-Krzysztoszek M. (2011), Mocne i stabe strony MSP. Ujęcie wedlug sekcji gospodarki [Strengths and weaknesses of SMEs: Sectoral perspective]. Warsaw: PKPP Lewiatan.

Tarute, A. and Gatautis, R. (2014), "ICT impact on SMEs performance", Social and Behavioural Sciences, Vol. 110, pp. 1218-1225.

Varis, M and Littunen, H. (2010), "Types of innovation, sources of information and performance in entrepreneurial SMEs”, European Journal of Innovation Management, Vol. 13, pp. 128-154.

Zapalska, A., Brozik, D. and Zieser, N. (2015), "Factors affecting success of small business enterprises in the Polish tourism industry", Turizam: znanstveno-stručni časopis, 63(3), pp. 365381. 
Table 1. Survey variables representing various effects in the conceptual model of Figure 1

\begin{tabular}{l}
\hline Empirical variables \\
\hline Exogenous variables (conditions) \\
Innovation type \\
- Innovation type implemented: process \\
- Innovation type implemented: product \\
- Innovation type implemented: organisation \\
- Innovation type implemented: marketing
\end{tabular}

Evidence base (categories)

Categorical (YES/NO)

Categorical (YES/NO)

Categorical (YES/NO)

Categorical (YES/NO)
Edwards et al. (2005)

Gunday et al. (2011)

Hall et al. (2009)

Hoffman et al. (1998)

Laforet (2013)

Lewandowska et al. (2016)

Mazur and Zaborek (2016)

Oke et al. (2007)

Radas and Bozic (2009)

Rosenbusch et al. (2011)

Varis and Littunen (2010)

Zapalska et al. (2015)

\section{Investment purpose}

- Purpose of the investment: increased competitiveness in national market

- Purpose of the investment: increased competitiveness in international market(s)

- Purpose of the investment: improved quality of goods/services

- Funding enabled initiation or increase in export

- Investment in Information and Communication Technologies

- Company has created the technology which is to be funded
Categorical (YES/NO)

Categorical (YES/NO)

Categorical (YES/NO)

Categorical (YES/NO)

Categorical (YES/NO)

Categorical (YES/NO)
Bailey and Kurland (2002)

Becchetti et al. (2003)

Bottazzi and Da Rin (2002)

Carayannis et al. (2013)

Cooke and Wills (1999)

Díaz-Chao et al. (2015)

Dmirel and Mazzucato

(2012)

Doraszelski and Jaumendreu (2013)

Golden (2012)

Grimes et al. (2011)

Hall et al. (2009)

Hashi and Krasniqi (2011)

Hill et al. (1998)

Hoffman et al. (1998)

Kandybin and Khin (2004)

Karhunen and Huovari

(2015)

Kmieciak et al. (2012)

Kossai and Piget (2014)

Lee et al. (2015)

Marsili (2006)

Martin et al. (2013)

Moen et al. (2016)

Norek (2013)

Piras et al. (2012)

Tarute and Gatautis (2014) 
Table 1. Survey variables representing various effects in the conceptual model of Figure 1 (continued)

\begin{tabular}{ccc}
\hline Empirical variables & $\begin{array}{c}\text { Variable format } \\
\text { (categories) }\end{array}$ & Evidence base \\
\hline
\end{tabular}

Funding and financial readiness

- Funding mechanism used

- Previous funding experience

- Independent investment readiness - strategy if funding not allocated

- Proportion of the investment that is selffunded
Categorical (SOP-ICE

2.2.1/2.3/2.4/ PHARE)

Categorical (SOP-ICE/ PHARE/ SAPARD)

Ordinal (proceed/ reduce or delay/ reduce and delay/abandon)

Continuous

(percentage)
Beck and Demirguc-Kunt

(2006)

Breznitz and Ornston (2017)

Czerniak and Stefański

(2016)

Heimonen (2012)

Hoffman et al. (1998)

Karpińska-Mizielińska, et al.

Keizer et al. (2002)

Mason and Kwok (2010)

Lee et al. (2015)

Radas and Božić (2009)

Categorical (YES/NO)

Adekola et al. (2008)

Beck and Demirguc-Kunt

(2006)
Categorical (YES/NO)

Categorical

(urban/rural)

Breznitz and Ornston (2017)
Bruton et al. (2014)

Hadjimanolis (1999)

Heimonen (2012)

Jankowska (2015)

Kaufmann and Tödtling

(2002)

Keizer et al. (2002)

Nowacki and Staniewski

(2012)

Radas and Božić (2009)

Agarwal and Audretsch

(2001)

(micro/small/medium)

Categorical (industry,

services,

trade/commerce)
uc-Kunt

(2006)

Heimonen (2012)

Hoffman et al. (1998)

Jones-Evans and Westhead

(1996)

Kowalski (2009)

Lee et al. (2015)

Hall et al. (2009) 
Table 1. Survey variables representing various effects in the conceptual model of Figure 1 (continued)

\begin{tabular}{|c|c|}
\hline \multirow{2}{*}{\multicolumn{2}{|c|}{$\begin{array}{c}\text { Empirical variables } \\
\text { Endogenous variables }\end{array}$}} \\
\hline & \\
\hline \multirow{2}{*}{$\begin{array}{l}\text { - Change in employment compared to base } \\
\text { year } \\
\text { - Increased the capital base (estates, } \\
\text { machines) }\end{array}$} & $\begin{array}{l}\text { Continuous } \\
\text { (percentage) }\end{array}$ \\
\hline & Categorical (YES/NO) \\
\hline - Change in unit price & $\begin{array}{l}\text { Ordinal (Lower/No } \\
\text { change/Higher) }\end{array}$ \\
\hline - Change in revenue compared to base year & $\begin{array}{l}\text { Continuous } \\
\text { (percentage) }\end{array}$ \\
\hline
\end{tabular}


Table 3. Results of model estimation $(n=110)$

\begin{tabular}{lrrr}
\hline Variable & $\begin{array}{c}\text { Change in employment } \\
\text { compared to base year }\end{array}$ & $\begin{array}{c}\text { Increased the } \\
\text { capital base }\end{array}$ & $\begin{array}{c}\text { Change in unit price } \\
\text { Change in revenue } \\
\text { compared to a base year }\end{array}$ \\
\hline $\begin{array}{l}\text { Direct effects of the endogenous variables } \\
\text { - Change in employment compared to the base year }\end{array}$ & & & \\
$\quad$ Increased the capital base (estates, machines) & - & $-0.041(0.684)$ & $0.261(0.001)$ \\
- Change in unit price & - & - & $-0.003(0.983)$ \\
\end{tabular}

Direct effects of the exogenous variables

Innovation type

- Innovation type implemented: process

- Innovation type implemented: product

- Innovation type implemented: organization

- Innovation type implemented: marketing

$-0.228(<0.001)$

Investment purpose and characteristic

- Purpose of the investment: increased competitiveness in national

market

- Purpose of the investment: increased competitiveness in

international market(s)

- Purpose of the investment: improved quality of goods/services

- Funding enabled initiation or increase in export

- Investment in Information and Communication Technologies

- Company has created the technology which is to be funded

Funding availability and financial readiness

- Funding mechanism used: SOP-ICE Purpose 2.3

- Previous funding experience: SOP (any purpose)

- Independent investment readiness - strategy if funding not

allocated

- Proportion of the investment that is self-funded
$-0.553(<0.001)$

$-0.445(<0.001)$
$0.043(<0.001)$ 
Table 3. Results of model estimation ( $n=110)$ (continued)

$\begin{array}{llccc}\text { Variable } & \begin{array}{c}\text { Change in employment } \\ \text { compared to base year }\end{array} & \begin{array}{c}\text { Increased the } \\ \text { capital base }\end{array} & \begin{array}{c}\text { Change in unit } \\ \text { price }\end{array} & \begin{array}{c}\text { Change in revenue } \\ \text { compared to a base } \\ \text { year }\end{array}\end{array}$

Location and collaboration

- Adoption of technology created at the request of the applicant in

co-operation with R\&D institution

- Investment in industrial park, scientific-technological park,

enterprise incubator

- Company's location: urban

Company size and sector

- Company size: small

- Company size: medium

$0.284(0.031) \quad-0.420(<0.001)$

- Sector of company's operation: industry

- Sector of company's operation: services

- Sector of company's operation: trade or commerce 
Table 2. Descriptive statistics of the data $(n=110)$

\begin{tabular}{|c|c|c|}
\hline Attribute & Number & $\%$ \\
\hline \multicolumn{3}{|l|}{ Company size } \\
\hline Micro (0-9 employees) & 9 & 8.2 \\
\hline Small (10-49 employees) & 44 & 40.0 \\
\hline Medium (50-249 employees) & 57 & 51.8 \\
\hline \multicolumn{3}{|l|}{ Revenue $(2007, \text { PLN })^{\mathrm{a}}$} \\
\hline Up to 30000 PLN & 1 & 0.9 \\
\hline $30001-100000$ PLN & 1 & 0.9 \\
\hline $100001-200000$ PLN & 1 & 0.9 \\
\hline $200001-1000000$ PLN & 8 & 7.3 \\
\hline $1000001-5000000$ PLN & 18 & 16.4 \\
\hline Above 5000000 PLN & 48 & 43.6 \\
\hline Refused to answer & 33 & 30.0 \\
\hline \multicolumn{3}{|l|}{ Location } \\
\hline Urban & 70 & 63.6 \\
\hline Rural & 40 & 36.4 \\
\hline \multicolumn{3}{|l|}{ Sector(s) of operation (multiple possible) } \\
\hline Production/manufacturing & 81 & 73.6 \\
\hline Services & 36 & 32.7 \\
\hline Trade/commerce & 8 & 7.3 \\
\hline Other & 1 & 0.9 \\
\hline \multicolumn{3}{|l|}{ Past EU-funding experience } \\
\hline SAPARD & 6 & 5.5 \\
\hline PHARE & 41 & 37.3 \\
\hline SOP-ICE & 79 & 71.8 \\
\hline Other & 5 & 4.5 \\
\hline None & 16 & 14.5 \\
\hline \multicolumn{3}{|l|}{ Support mechanism used } \\
\hline SOP-ICE & 110 & 100 \\
\hline SOP-ICE sub-purpose 2.2.1: Support for companies undertaking investments & 19 & 17.3 \\
\hline SOP-ICE purpose 2.3: Increase in SME's competitiveness through investments & 109 & 99.1 \\
\hline SOP-ICE purpose 2.4 Support for environmental standards adjustments for companies & 1 & 0.9 \\
\hline PHARE & 19 & 17.3 \\
\hline Other & 3 & 2.7 \\
\hline \multicolumn{3}{|l|}{ Innovation type implemented } \\
\hline Process & 76 & 69.1 \\
\hline Product & 80 & 72.7 \\
\hline Organization & 22 & 20.0 \\
\hline Marketing & 5 & 4.5 \\
\hline \multicolumn{3}{|l|}{ Investment purpose } \\
\hline Increase in national competitiveness & 84 & 76.4 \\
\hline Increase in international competitiveness & 55 & 50.0 \\
\hline Quality improvement & 69 & 62.7 \\
\hline Development of export strategy & 24 & 21.8 \\
\hline Other & 5 & 4.5 \\
\hline
\end{tabular}

a $1 \mathrm{PLN} \approx 0.263$ EUR (on average during the study period) 


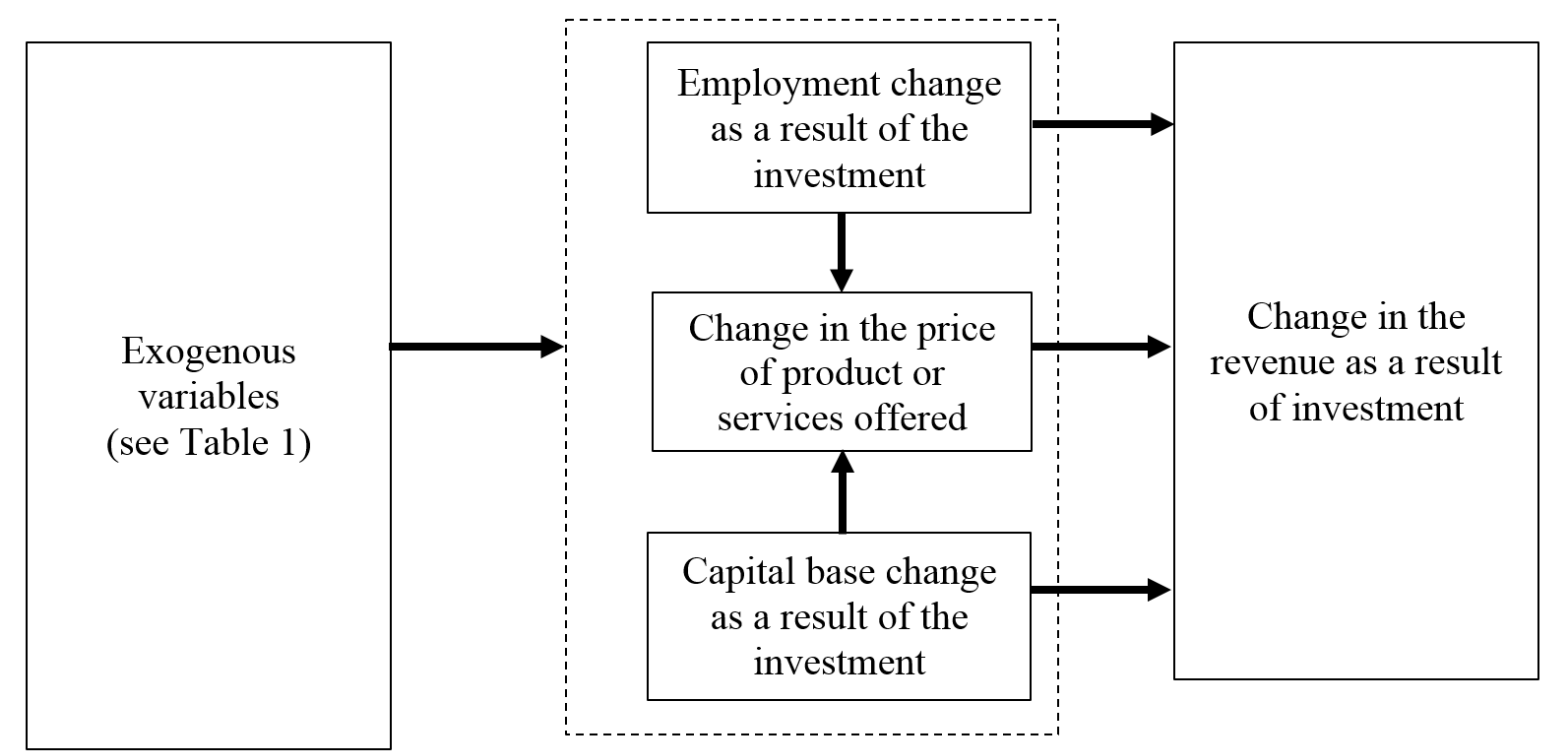

Figure 1. Conceptual model of interaction between investment conditions and changes to employment, price and revenue 